\title{
Climate Change in Poultry Production System - A Review
}

\author{
Ahaotu EO ${ }^{1}$, Patricio De los Ríos ${ }^{2}$, Ibe $\mathrm{LC}^{3}$ and Singh RR ${ }^{4}$ \\ ${ }^{1}$ Department of Animal Production Technology, Imo State Polytechnic Umuagwo, Nigeria \\ ${ }^{2}$ Universidad Católica de Temuco, Facultad de Recursos Naturales, Departamento de Ciencias Biológicas y Químicas, Temuco, Chile \\ ${ }^{3}$ Department of Estate Management, School of Environmental Management Technology, Imo State Polytechnic Umuagwo, Nigeria \\ ${ }^{4}$ Department of Livestock Production Management, Vanbandhu College of Veterinary Science and AH, Navsari Agricultural University, \\ Navsari, Gujarat, India
}

*Corresponding Author: Ahaotu EO, Department of Animal Production Technology, Imo State Polytechnic Umuagwo, Nigeria.

Received: June 13, 2019; Published: August 16, 2019

DOI: $10.31080 /$ ASAG.2019.03.0617

\begin{abstract}
Due to the tremendous growth and unpredictable figures of production in Nigerian poultry sector, there are several problems affecting growth of the industry, among which are environmental challenges which imposes severe stress on birds thus leading to reduced performance. Invariably, reviewing the impacts of heat stress on poultry production seems to be the main research area in the present study. The purpose of this article therefore is to review the seasonal fluctuations and its detrimental effects on poultry production systems.
\end{abstract}

Keywords: Poultry Production; Seasonal Fluctuations; Environmental Challenges; Management

\section{Introduction}

Poultry plays a vital role in the livelihood of rural households in Africa, especially Nigeria [1]. Poultry are birds which render economic services to humans as a primary supplier of meat, egg and raw materials to industries (feathers, waste products), source of income and employment to people compared to other domestic animals [2]. Poultry convert feed to egg and meat within a short period of time [3].

Developing the poultry industry in Nigeria will be the fastest means of bridging the protein deficiency gap prevailing the country [4]. Whenever ambient temperature is high, chickens tend to have higher energy needs than when in thermo-neutral environments. Major losses result from a less efficient conversion of feed to meat; this also affects poultry health and productivity [5].

Poultry flocks are particularly endangered to climate change due to a range of thermal conditions which affects the animals' behavioural and physiological activities [1]. Hence, birds can only tolerate lowly temperature ranges to sustain the peak of their production for human consumption. The environmental conditions affecting the performance of chicken include temperature, relative humidity and light at a given time [6]. Ambient temperatures significantly influence the survivability and performance of the poultry production [2]. Ahaotu., et al. [7] stated that as the ambient temperature increased to $34^{\circ} \mathrm{C}$, the mortality due to heat will be higher in broilers by $8.4 \%$. As the feed consumption of the chickens decreases from $108.3 \mathrm{~g} / \mathrm{bird} /$ day at $31.6^{\circ} \mathrm{C}$ to $68.9 \mathrm{~g} / \mathrm{bird} /$ day at $37.9^{\circ} \mathrm{C}$, the egg production will be reduced by $6.4 \%$ [5].

Understanding and controlling environmental conditions is crucial to successful poultry production and welfare. The purpose of this article is to review some of the effects of heat stress on poultry and to look at methods that can be used by the poultry producers to partially alleviate some of the detrimental effects of seasonal fluctuations on the poultry productivity.

\section{Thermoregulatory mechanism of poultry birds}

The internal body temperature of domesticated gallinaceous birds (chickens) at $106^{\circ} \mathrm{F}$ to $108^{\circ} \mathrm{F}$ is measurably higher than that of mammalian livestock and humans $\left(97^{\circ} \mathrm{F}\right.$ to $\left.102^{\circ} \mathrm{F}\right)$ [8].

\section{Methods of heat loss in poultry}

During the dry season, when daily temperatures reach at their extremes, it affects poultry production drastically. Poultry do not sweat and therefore must dissipate heat in other ways to maintain their body temperature at approximately $105^{\circ} \mathrm{F}$. Body heat is dissipated to the surrounding environment through radiation, conduction, convection and evaporation [9]. The proportions of heat lost due to seasonal fluctuations depend upon the temperature difference between the bird and its environment [10]. 
The purpose of poultry house ventilation is to maintain a high or low air velocity in the house so that the birds can maintain body temperature by sensible heat loss. Once the environmental temperature reaches approximately $77^{\circ} \mathrm{F}$, the method of heat loss begins shifting from sensible to evaporative heat loss (Figure 1).

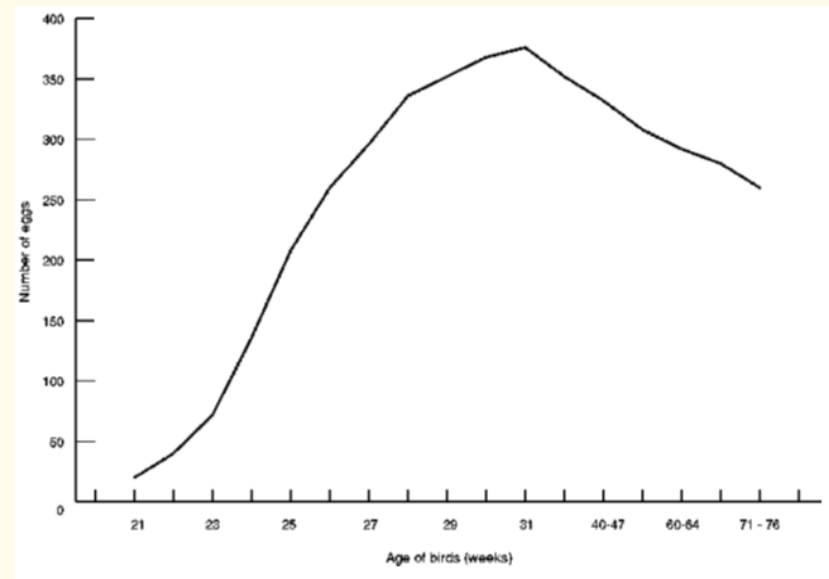

Figure 1: Changes in present hen/day production with age of laying birds.

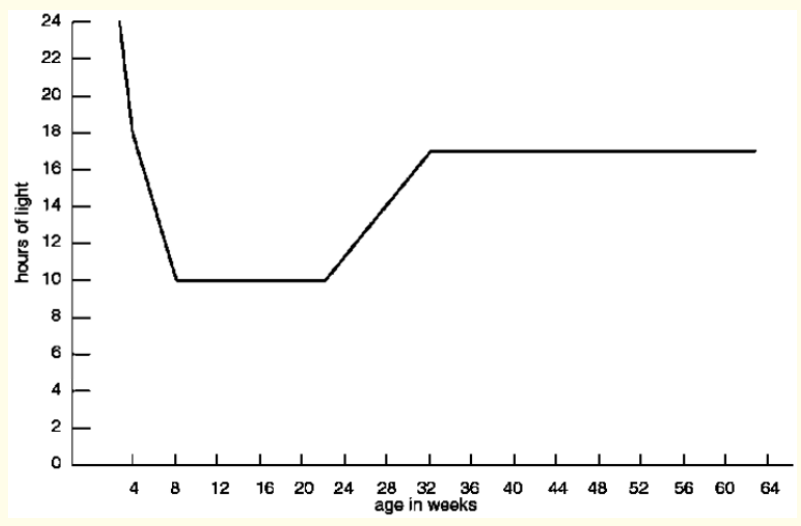

Figure 2: Lighting Schedules.

\section{Lighting Schedule}

Egg production is stimulated by daylight; therefore, as the days grow longer production increases. In open houses, found commonly in the tropics, artificial lighting may be used to increase the laying period. When darkness falls artificial lighting can be introduced for two to three hours, which may increase egg production by 20 to 30 percent. In closed houses, where layers are not exposed to natural light, the length of the artificial day should be increased either in one step or in a number of steps until the artificial day reaches 16 to 17 hours, which will ensure constant and maximized egg production. Effective day length should never decrease during the laying period [9].

\section{Seasonal fluctuations}

Seasonal Fluctuations is a worldwide problem in poultry production, especially in broiler and layer lines. Seasonal fluctuations begin when the ambient temperature climbs above $80 \mathrm{oF}$ and is readily apparent above $85^{\circ} \mathrm{F}$ [11]. When a bird begins to pant, physiological changes started within its body to dissipate excess heat.

High ambient temperatures can be devastating to commercial broilers; coupled with high humidity they can have an even more harmful effect. Seasonal Fluctuations interferes with the broilers comfort and suppresses productive efficiency, growth rate, feed conversion and live weight gain [5]. In poultry production, seasonal fluctuations can be described as acute or chronic. Acute heat stress refers to short and sudden periods of extremely high temperature, whereas chronic heat stress refers to extended periods of elevated temperature.

Chronic stress also has deleterious effects on birds reared in open-sided houses mainly through reducing feed consumption and increasing water consumption. Most of the reduction in feed consumption will be due to reduced maintenance requirement. In broilers, growth rates, feed efficiency and carcass quality are negatively affected [12].

In breeders, high ambient temperature coupled with high humidity decreases fertility resulting in low hatchability. Seasonal fluctuations period has a negative effect on gamete formation and the fertilization process.

\section{Clinical signs and symptoms of seasonal fluctuations}

Poultry subjected to high environmental temperatures exhibit many behavioural and physiological changes which allow them to re-establish heat balance with their surroundings. As ambient temperature increases, chicken spend less time in feeding, more time in drinking and panting [10]. Usually, their wings are spread away from the body to promote cooling by reducing body insulation and they splash water on their combs and wattles in order to increase evaporative cooling from these surfaces [9].

\section{Effect of seasonal fluctuations on poultry production system}

Birds exposed to high environmental temperature generate behavioral, physiological and immunological responses which causes more harm to their performance and productivity. Hot climate can have a severe impact on poultry performance thus resulting to heavy economic losses on poultry production as a result of stunted growth [13], decrease in hen-day production [14], higher cost of production, higher mortality due to depressed immunity and reproductive failure [15]. 


\section{Growth and production efficiency}

Seasonal fluctuations depress growth rate and production as a result of a down-turn in voluntary feed intake in birds [16]. It is apparent that the inhibition of growth and production in heatstressed broiler birds is mediated via the stress hormones, especially the corticosteroids.

Seasonal fluctuations further results to decreased feed consumption and increased water consumption. As temperature rises, the bird has to maintain the balance between heat production and heat loss and thereby reducing its feed consumption. to reduce heat from metabolism. Imik., et al. [17] in their study showed that impaired growth performance in broilers is subjected to seasonal fluctuations.

\section{Egg quality}

Seasonal fluctuations limits the productivity of laying hens, as reflected by egg production and egg quality, as the bird diverts feed metabolic energy to maintain its body temperature constant, resulting in lower egg production, and particularly in lower egg quality [5]. Under high environmental temperatures, layer respiratory rate increases from eases from approximately 29 cycles per minute (mild environmental temperatures) to more than 100 cycles per minute (environmental temperatures above the thermo neutral zone). The resulting hyperventilation decreases Carbondioxide blood levels, which may decrease eggshell thickness in approximately $12 \%$ [9]. Carbondioxide is responsible for eggshell quality improvement, as it may promote acidosis, which is subsequently compensated by kidney uptake of bicarbonate. Therefore, seasonal fluctuations causes losses in egg weight, egg shell percentage, egg shell weight, and egg specific gravity [18].

\section{Meat quality}

Seasonal fluctuations could affect meat quality by either direct effect on organ and muscle metabolism during heat exposure which can persist after slaughter. For example seasonal fluctuations can increase the risks of pale-soft-exudative meat in turkeys, heat shortening in broilers and dehydration in most species. Also changes in poultry management practices in response to hazards that stem from seasonal fluctuations could indirectly lead to changes in meat quality [19].

Pre-conditioning broilers to seasonal fluctuations to encourage better survival during transport could lead to more variable breast meat $\mathrm{pH}$. The impacts that short term seasonal fluctuations could have will vary between regions [20]. It has been reported that chronic heat exposure negatively affects fat deposition and meat quality in broilers, in a breed-dependent manner [19]. In fact, recent studies demonstrated that heat stress is associated with depression of meat chemical composition and quality in broilers [21].

\section{Reproductive performance}

Seasonal fluctuations caused decreased production performance, as well as reduced eggshell thickness, and increased egg breakage [22]. Additionally, seasonal fluctuations has been shown to cause a significant reduction of egg weight (3.24\%), egg shell thickness (1.2\%), eggshell weight (9.93\%), and eggshell percent (0.66\%) [19].

Seasonal fluctuations affect all phases of semen production in breeder cocks [23]. Although limited high temperature stimulates testicular growth in the early phase and promotes increased semen volume and concentration, a subsequent rise suppresses reproductive capacity as a result of a decrease in seminiferous epithelial cell differentiation, which is manifested in decreased semen quality and quantity with time [18]. Ahaotu., et al. [24] showed that the fertility of broiler male declined to $42 \%$ exposed to a temperature of $32^{\circ} \mathrm{C}$.

\section{Embryonic development}

The incidence of adverse effects of seasonal fluctuations on embryonic growth has been reported by various workers. Uzoma., et al. [19] showed that over-heating fertile eggs during incubation resulted in differential tissue growth at different stages of incubation. The finding further showed asymmetries in skeletal development during the early and late stages of embryo development.

\section{Immunity}

In poultry, several studies have investigated the effects of seasonal fluctuations on the immune response in recent years. In general, all studies showed an immunosuppressing effect of seasonal fluctuations on broilers and laying hens. Lower relative weights of thymus and spleen has been found in laying hens subjected to seasonal fluctuations also reduced lymphoid organ weights and reduced liver weights have also been reported in broilers under seasonal fluctuations conditions [25].

\section{Disease incidence}

Uzoma., et al. [19] reported that seasonal fluctuations will alter global disease distribution. High temperature has tremendous effect on prevalence of zoonotic diseases as well. Seasonal fluctuations may also increase the insect vectors, prolong transmission cycles, increase the importation of vectors and animal reservoirs. It may also have an adverse effect on biodiversity, distribution and migratory pattern of birds which may lead to emergence of disease outbreaks.

Seasonal fluctuations could also alter bird migration, influence the avian influenza virus transmission cycle and directly affect virus survival outside the host. In domestic poultry, the direct effect of environmental factors on highly pathogenic avian influenza transmission and persistence allows inference to have possible effect of seasonal fluctuations. 
Seasonal fluctuations alters global disease distribution, affects poultry feed intake, encourage outbreak of diseases which invariably affects poultry output (egg and meat) and also cost of production [19,26-29].

\section{Conclusion}

Effects of seasonal fluctuations which results in increased in sunshine intensity and global warming has a negative effects on poultry production which many at times results to high mortality rate of the chickens, low egg and meat production and prices of feed grains are usually high in hot and dry seasons as result of effects of seasonal fluctuations which may affect cost of production and number of birds to raise for egg and meat production in the farm.

Egg and meat production pattern are affected by seasonal fluctuations because periods of high temperature and sunshine intensity makes the birds to drink more water and reduce feed intake which many at times results to high mortality of the chickens, low egg production and low feed conversion ability of the birds to meat, hence, low meat production.

The review also revealed that seasonal fluctuations influence the emergence of new poultry diseases and increased its distribution. There is need to intensify awareness campaign to poultry farmers on how to reduce the effects of seasonal fluctuations on poultry production. Extension agents and other development agencies need to educate the poultry farmers more about the effects posed by seasonal fluctuations on poultry production.

\section{Bibliography}

1. Ayo-Enwerem, M.C; Ahaotu, E.O; Nwogu, C. M. and Opara, J. (2017a). Growth performance of starter broilers fed diets containing red sandalwood (Pterocarpus santolinoides) leaf meal. Direct Research Journal of Veterinary Medicine and Animal Science. 2 (4): 106-109.

2. Ayo-Enwerem, C.M, Ahaotu, E.O, Nwogu, C.M and Esukpa, M (2017b). Haematology and Serum Biochemistry of Starter Broilers Fed Diets Containing Red Sandalwood (Pterocarpus santolinoides) Leaf Meal. Direct Research Journal of Veterinary Medicine and Animal Science. 2 (4): 111-114.

3. Ahaotu, E.O, Onuoha, $\mathrm{W}$ and Uwaleke, G and Agiang, E.A (2019a). Sustainability of black Nera laying birds on pig dung meal based diets. Sustainability, Agri, Food and Environmental Research. 7(1) : 1-17

4. Is-Haaq A.T , Ahaotu E.O , Onumajuru C.G, Akinfemi . A and Mako A. A (2018). Replacement value of Puerairia phaseoloides leaf meal for soya bean meal on the Performance and carcass evaluation of starter broilers. Journal of Research in Microbiology and Biotechnology. 1 (1): 5-9.
5. Okonkwo, S and Ahaotu, E.O (2019). "Management of Laying Birds in Deep Litter and Battery Cage Systems In Orlu Local Government Area of Imo State, Nigeria: A Comparative Study." Journal of Agricultural, Biological and Environmental Sciences, $6: 20-27$.

6. Pragya, B, J.M. Kataria, S. Majumdar, S.K. Bhanja, Divya and G. Kolluri (2014). Impact of Hot Climate on Poultry Production System-A Review. Journal of Poultry Science and Technology. 2 (4): 56-63.

7. Ahaotu E.O, Nwoye E.0 and Lawal Muhammad (2019b). Biochemical Constituents, Economics of Production and Performance of Starter Broilers Fed Diets Supplemented with Natural Feed Additives. International Journal of Animal and Veterinary Sciences. $06:$ 01-05

8. Ahaotu, E.O, Nwafor, C, Onyebuchukwu, P.A, and Okpara, O (2019c). Carcass, Organ Weights and Egg Quality Characteristics of Guinea Fowl Layers Fed Varying Levels of Butterfly Pea Leaf (Centrosema Pubescens) Meal. Sustainability, Agri, Food and Environmental Research. 7(1): 37 - 51.

9. Ahaotu, E.O and U.T Agunanne (2017). Egg Production Pattern In Anthony Patience Farms, Atta-Ikeduru, Imo State, Nigeria: Influences On The Phase Of Production And The Estimated Period Of Oviposition. Proc. 6th ASAN-NIAS Joint Annual Meeting. Sept 10-14, 2017. Pp 375-380.

10. Mack LA, Felver-Gant, JN, Dennis RL and Cheng HW (2013). Genetic variation alter production and behavioral responses following heat stress in 2 strains of laying hens. Poultry Science, 92: 285-294.

11. Adesiji, G.B., Tyabo. I.S., Bolarin, O. Ibrahim, M. and Baba, S. T. (2013). Effects of Climate Change on Poultry Production in Ondo State, Nigeria. Ethiopian Journal of Environmental Studies and Management . 6 (3):242-248.

12. Odey M. A , Ahaotu, E.O , Patricio, D. L and Anonya, F.F (2019). Effect of Supplemental Moringa Oleifera Leaf Meal on Performance of Starter Broiler Birds. International Journal of Research in Agriculture and Forestry, 6 (4): 1-9

13. Ahaotu, E.O, Ihenacho, R.A and Ayo - Enwerem, C.M (2017). Performance of Nera black layer birds fed feather meal supplemented with fish meal. Proc. 6th ASAN-NIAS Joint Annual Meeting. Sept 10-14, 2017. Pp 608-611

14. Ononiwu, C.C, Ahaotu, E.O, V.N.Okonkwo, C.M. Ayo-Enwerem and H. Botchway (2017). Effects of Bambara Nut Sievate Fortified Exogenous Enzyme on Performance and Carcass Characteristics of Finisher Broiler Birds. Proceedings of the 20th Biennial Conference, Ghana Society of Animal Production (GSAP), 1-5 August, 2017. Sasakawa Centre, University of Cape Coast, Ghana Pp 73-80. 
15. Nkwocha, G.A., K.U. Anukam, E.O. Ahaotu and O.I. Prudent (2018). Performance and Hematological Profile of Broiler Chicks on Toasted Tiger Nut (Cyperus esculentus) Treated With Bakery Yeast. Proc. 43rd Annual Conference of the Nigerian Society for Animal Production, March 18th - 22nd 2018, FUT Owerri, Nigeria. Pp 484 - 487.

16. Sohail MU, Hume ME, Byrd JA, Nisbet DJ, Ijaz A, Sohail A, Shabbir, MZ and Rehman H (2012). Effect of supplementation of prebiotic mannan-oligosaccharides and probiotic mixture on growth performance of broilers subjected to chronic heat stress. Poultry Science, 91: 2235-2240.

17. Imik H, Ozlu H, Gumus R, Atasever, MA, Urgar S and Atasever $M$ (2012). Effects of ascorbic acid and alpha-lipoic acid on performance and meat quality of broilers subjected to heat stress. British Poultry Science, 53: 800-808.

18. Onyekwere M.U., Okechukwu, S.O., Jiwuba, P. C., Onwujiariri, E.B. Ahaotu, E.O and Anukam K.U. (2016). Effect of dried cocoyam tubers (Colocasia esculenta) meal on growth performance and blood serum mineral profile fed broiler starter. Proc. 21st Ann. Conf. Animal Science Association of Nigeria. Porthacourt, Rivers State. 18th -22nd Sept, 2016. Pp 184 - 189.

19. Uzoma, U. F, Ahaotu, E.O, Olowo, P and Nyako, H.D (2019). Response of High Dietary Energy Profile Meal from Processed Maize Products on Performance Parameters and Egg Quality of Shaver Brown Laying Birds. International Journal of Research in Agriculture and Forestry. 6 (1): 29-37.

20. Dai SF, Gao F, Xu XL, Zhang WH, Song SX and Zhou GH (2012). Effects of dietary glutamine and gamma-amino-butyric acid on meat colour, $\mathrm{pH}$, composition, and water-holding characteristic in broilers under cyclic heat stress. British Poultry Science, 53(4): 471-481.

21. Zhang, ZY, Jia GQ, Zuo JJ, Zhang Y, Lei J, Ren L and Feng DY (2012). Effects of constant and cyclic heat stress on muscle metabolism and meat quality of broiler breast fillet and thigh meat. Poultry Science, 91: 2931-2937.

22. Ebeid TA, Suzuki T and Sugiyama T (2012). High temperature influences eggshell quality and calbindin-D28k localization of eggshell gland and all intestinal segments of laying hens. Poultry Science, 91: 2282-2287.

23. Ahaotu, E.O, Okorie, K.C and Akinfemi, A (2018). Effects of Amaranthus Spinosus (Green) Leaf meal on the Performance of Hubbard Broiler Chicks. Macedonian Journal of Animal Science, Vol. 8 (2): 77-80.
24. Ahaotu, E.O., V.N. Okonkwo, K.C. Okorie and A. Akinfemi (2016). Effects of Bambara Nut Sievate Supplemented Exogenous Enzymes on Haematology and Serum Biochemical Value of Finisher Broiler Birds. Book of Proceedings of Academic Conference on Positioning Sub-Saharan Africa for Development in the New Development. 22-23rd June, 2016, Cambridge Hall, University of Ghana, Legon Campus, Accra. Vol. 9 (1): $32-39$.

25. Ghazi SH, Habibian M, Moeini MM and Abdol Mohammad AR (2012). Effects of different levels of organic and inorganic chromium on growth performance and immuno-competence of broilers under heat stress. Biological Trace Element Research, 146: 309-317.

26. Adewale, I.T, Ahaotu, E.O, Onyekwere, M.U, Olaoye, J.C and Ikpe, J.N (2018). Serum Biochemical Indices and Haematological Profiles of broiler Birds Fed Varying Levels of Biscuit Waste Meal Based Diets. Int J Anim Sci. 2 (5): 1032-1035.

27. FAO (2014). Food Outlook. Food and Agricultural Organisations of the United Nations. Rome, Italy http://www.fao. org/3/a-i4136e.pdf

28. Felver-Gant JN, Mack LA, Dennis RL, Eicher SD and Cheng HW (2012). Genetic variations alter physiological responses following heat stress in 2 strains of laying hens. Poultry Science, 91: 1542- 1551.

29. Tripathi A, Kumar N and Chauhan DK (2017). Understanding Integrated Impacts of Climate Change and Pollution on Ganges River System: A Mini Review on Biological Effects, Knowledge Gaps and Research Needs. SM J Biol. 3(1): 1017-1027.

\section{Volume 3 Issue 9 September 2019 \\ (C) All rights are reserved by Ahaotu EO., et al.}

